\title{
Mending Seams: A Study of Information Barriers Related to Textile Artists
}

\section{S. A. Vander Kooy}

Word Count (excluding references): 5616

\begin{abstract}
An important aspect of studying information behaviour is understanding the various barriers that can impede an individual's efforts to seek and find specific information. Yet, when it comes to artists, the focus of such research has consistently veered away from the topic. This article explores the information and resource needs of textile artists and the barriers that prevent them from meeting those needs. A semi-structured interview of an experienced textile artist was conducted and directed, in addition to conventional content analysis being used to examine the data. The data revealed six sources textiles artists utilize for locating resources and eight information barriers that influence their ability to meet their information needs. The significance of these findings is then discussed and potential solutions are presented for information professionals particularly public librarians - to implement.
\end{abstract}

Keywords: information barriers; information seeking behaviour; textile artists; public libraries

Vander Kooy, S. A. (2019). Mending seams: a study of information barriers related to textile artists. Emerging Library \& Information Perspectives, 2, 81-114. https://doi.org/10.5206/elip.v2i1.6209 


\section{Introduction}

A primary goal of studying information behaviour is to provide a clearer understanding of why and how individuals seek information so that information professionals, particularly librarians, can develop better systems to accommodate those needs. An important aspect of this research is understanding the various barriers that can impede an individual's efforts to find specific information. Yet, when it comes to artists, the focus of such research has remained fixated on modeling artists' information-seeking behaviour and cataloguing the assorted resources they use. Although this has advanced librarians' knowledge regarding how to interact with artists, create programming for artists, and develop collections specific to artists, it has failed to address key barriers that artists face. This paper explores the information and resource needs of textile artists and the barriers that prevent these artists from meeting those needs as well as some potential solutions information professionals can implement to resolve these barriers.

\section{Literature Review}

\section{Textile Artists and Information Seeking Behaviour}

The word "craft" often invokes images of children constructing items from coloured paper, glue, and other common household materials. Yet, the word itself is derived from the Old English cræft, meaning strength and skill (Craft, n.d.). Given this, it is curious that the "practices and products of craft have held an ambivalent cultural status throughout history" (Poser, 2008, p. 81). According to Visser (1994), crafts, such as textile handworks like knitting, weaving, and embroidery, are often marginalized. "The word 'crafts' has come to be used for hobbies... And crafts that are not done for money 
are by that very token, in the modern world, activities not to be taken seriously" (Visser, 1994, p. 13). Where art is praiseworthy, crafts carry a patronizing connotation because unlike art, which is produced solely for contemplation and beauty, crafts have utilitarian uses (Visser as cited by Prigoda \& McKenzie, 2007, p. 92). However, many crafters would argue that their creations are art. In fact, when studying the information seeking behaviour (ISB) of artists, Cobbledick (1996) included a "fiber artist" among her four interview subjects. Likewise, Medaille's (2010) study of ISB among theatre artists, Mason and Robinson's (2011) study of ISB among emerging artists, and Lo and Chu's (2015) study of ISB among students at Hong Kong's Design Institute all included "artists" who worked with textiles. Thus, it seems fair to say that the ISB of textile artists (i.e. crafters who create works, both for utilitarian and artistic purposes, from textiles) is highly similar to that of other artists.

Cobbledick (1996) identified five purposes for which artists seek information: (1) inspiration, (2) specific visual elements, (3) knowledge of materials and techniques, (4) marketing and career guidance, and (5) knowledge of current trends. Hemmig (2008) verified these five purposes through an extensive literature review, but he argued that the fifth category is indistinct and can therefore be subsumed by the other four. "Keeping up with current trends can easily be seen as a means of acquiring inspiration, technical knowledge, and business information" (Hemmig, 2008, p. 355). Hemmig later confirmed this hypothesis in his 2009 study of practicing visual artists' ISB. Mason and Robinson (2011) further corroborated Hemmig's hypothesis when their study demonstrated that the ISB of emerging artists is "largely the same as that of the broader professional group" (p. 178). However, they also found that two things needed to be 
taken into consideration. First, as many emerging artists lack money and resources, they often look for free or cheap information. Second, due to their need to establish themselves, emerging artists seek a forum for discussion, debate, and advice related to their work and career.

This idea of artists sharing information is a common one. In fact, Lave and Wenger (1991) argued, "A community of practice is an intrinsic condition for the existence of knowledge" (p. 98). According to Hemmig (2008), the artists themselves, their social networks, and the limitless range of information sources that contribute to the creation and sale of their work can be considered a community of practice (p. 357). Additionally, from a collectivist perspective, "Communities collectively construct information needs, seeking, sources, and uses" (Prigoda \& McKenzie, 2007, p. 91). As Medaille (2010) found in a study of "theatre artists," for example, they "enjoy sharing information with other artists, and the back-and-forth process of independent search and group information exchange provides them with a constant source of stimulation" (p. 344). Thus, the communities in which artists participate provide a vital resource when it comes to information seeking. Many studies note that this is particularly true when it comes to knowledge of techniques, materials, and, as stated above, career guidance (Hemmig, 2009, p. 684).

Regarding other resources, Hemmig's (2009) literature review revealed that the information needs of individual artists are extremely idiosyncratic and artists often require a great deal of information that is unrelated to art (p. 684). This means that artists utilize a large variety of resources. Mason and Robinson listed nearly 300 resources used for inspiration alone in their article regarding the ISB of emerging artists 
(2011, pp. 167-176) and Lo and Chu (2015) asserted that "there are essentially no boundaries to what [artists] could count as 'art information'” (p. 116). There is also widespread agreement that these tendencies mean that libraries - particularly public ones, due to their minimal costs and diverse information sources - are best suited to serving the information needs of artists (Hemmig, 2009, p.696). This realization has led to the following recommendations:

- library collections should contain print materials whose verbal and visual content covers a wide variety of topics;

- items that are typically non-circulating (i.e. encyclopedias, magazines, periodicals, etc.) should be considered for circulation;

- catalogue descriptions should include information about items' visual content;

- high-quality photocopying and printing should be made available;

- while browsing is considered artists' preferred ISB its importance should not be overstated, as artists will still seek face-to-face encounters;

- artists often prefer smaller or local libraries due to their quiet and comfortable environments; and

- libraries can provide beneficial communal gathering spaces for artists (Cobbledick, 1996; Hemmig, 2009; Medaille, 2010; Mason \& Robinson, 2011; Beaudoin, 2014; and Lo \& Chu, 2015).

\section{Textile Artists and Information Barriers}

In terms of the information barriers that artists experience, very little research exists, and nothing addresses it directly. Medaille (2010) notes that theatre artists are susceptible to information overload, which can stifle their creative impulses, but offers 
no concrete suggestions on how to prevent this issue from occurring (p. 343). Mason and Robinson (2011) discuss emerging artists' preference for free or cheap information, but they frame this as a trend rather than as a potential response to a barrier (p. 178). Only Hemmig (2009) attempts to address the notion of barriers by asking his survey respondents to "underline any sources that they have difficulty locating" from a provided list (p.695); however, none of the respondents did so. This led Hemmig (2009) to conclude that visual artists may not be "cognizant of omissions in their information environments" (p. 699). Given Medaille's (2010) and Mason and Robinson's (2011) findings, though, this conclusion seems unlikely.

Information barriers can exist as both physical and immaterial obstacles. This means that information seekers can be impeded by both external and internal factors when searching for information. External barriers originate outside the individual. These barriers can be temporal in nature, such as having insufficient time to perform a search (Savolainen, 2016, p. 52). They can be spatial in nature, such as information resources being physically inaccessible or the specific features of a space being problematic, like uncomfortable furniture or too much ambient noise (Savolainen, 2009, p. 44). They can also be socio-cultural in nature.

In a study on external information barriers, which focused exclusively on sociocultural factors, Savolainen (2016) identified six main types of socio-cultural barriers that can affect information seekers. The first type is barriers due to language problems, which can include issues such as a lack of language proficiency or an over-reliance on gatekeepers. The second type is barriers related to social stigma and cultural taboo, which can include issues such as feeling like an outsider, lacking social support, or 
mistrusting others. It can also include information being concealed due to societal prohibitions or a fear of punishment for seeking such information. The third type is barriers related to small-worlds, and unlike barriers related to social stigma and cultural taboo, small-world barriers "are confined to certain local communities that are relatively closed to outsiders" (Savolainen, 2016, p. 54). These barriers include issues such as labeling sources of information as either useful or useless depending on how they reflect the community's values and beliefs (Chatman, 1999, p. 214), avoiding information that might endanger a member's position within the community (Chatman, 1996, p. 200), or being distrustful of information presented by people outside the community (Hayter, 2006, pp. 29-30). The fourth type is institutional barriers, which can include issues like excessive bureaucracy, authoritarian control (i.e., censorship or bureaucratic inertia), insufficient resources (i.e. materials or staff), or poor organization (i.e., inadequate classification system). The fifth type is organizational barriers. Where institutional barriers create obstacles between the seeker and the service provider, organizational barriers impede the ability of employees to work cooperatively within individual organizations. These barriers include issues like hierarchies, internal competitions, lack of trust, deception and secrecy, unwillingness to value the work of others, and so on. The sixth type is barriers due to the lack of social and economic capital, and these can include issues like a poor contact network or insufficient funds.

In contrast to external barriers, internal barriers are ones that originate from within the individual. These barriers can be divided into two categories: cognitive and affective. Cognitive barriers often stem from failures in information transfer, which occur when either the exchange of information is problematic or access to the information is 
impaired or denied (Harris \& Dewdney, 1994, p. 4). Specific barriers related to failures in information transfer include poor search skills, an inability to articulate an information need, and a lack of awareness of relevant information or information sources (Harris \& Dewdney, 1994, p. 3). ${ }^{1}$ Additional cognitive barriers can include an unwillingness to acknowledge an information need, low self-efficacy in information seeking, and an inability to handle information overload (Savolainen, 2015a, p. 620).

Conversely, affective barriers often stem from negative emotions such as anxiety, apprehension, fear, doubt, confusion, embarrassment, and frustration (Savolainen, 2014; Savolainen, 2015b). These emotions can lead information seekers to leave their searches unfinished because the task has become too onerous and/or because they want to avoid or blunt potentially intimidating information. For example, if an individual is struggling with their finances, they may quickly become overwhelmed by the sheer amount of information available on various purported solutions for their situation. They may also avoid reading certain information, such as government aid options, because they fear the worst-case scenario - they do not qualify for help - may apply to them.

Broadly speaking, all of these information barriers can be organized in relation to one of four sources: (1) barriers related to the individual, (2) barriers related to the social group or society, (3) barriers related to the information provider, and (4) barriers related to the information itself. A representation of this distillation can be seen in Table 1. Regardless of the type of information barrier or where it stems from, all barriers lead to

\footnotetext{
${ }_{1}^{1}$ Although barriers related to failures in information transfer are primarily cognitive in nature, some stem from institutional issues, such as the information being delayed, inaccurate, or inappropriate (Harris \& Dewdney, 1994, pp. 3-4).
} 
information seeking being hindered, restricted, delayed, or otherwise negatively affected (Savolainen, 2016, p. 57).

\begin{tabular}{|l|l|l|l|}
\hline \multicolumn{3}{|c|}{ TABLE 1: Information Barriers } \\
\hline \multicolumn{1}{|c|}{ Individual } & \multicolumn{1}{|c|}{ Social } & \multicolumn{1}{|c|}{$\begin{array}{c}\text { Information } \\
\text { Provider }\end{array}$} & Information Itself \\
\hline Attention & $\begin{array}{l}\text { Censorship } \\
\text { Avoidance }\end{array}$ & Bias & Accessibility \\
Blunting & Information poverty & Communication \\
Skills & Availability \\
Skills & Insider/Outsider & Filters & Quality \\
Distraction & Lacking funds & Inaccuracy & Quantity \\
Insufficient time & Lacking privilege & Inconvenience & \\
Lack of & Lacking trust & Selection & \\
acknowledgement & $\begin{array}{l}\text { Physical } \\
\text { inaccessibility } \\
\text { Literacy/llliteracy }\end{array}$ & Small worlds & \\
Monitoring & & & \\
Negative emotions & & \\
Searching skills & & & \\
\end{tabular}

\section{Research Questions}

The analysis presented in this study seeks to answer the following questions:

$R Q 1$. What resources do textile artists use to satisfy their information needs?

$R Q 2$. How do textile artists acquire these resources? 
$R Q 3$. What barriers do textile artists encounter related to their information needs?

$R Q 4$. How do textile artists attempt to circumnavigate or deal with these barriers?

\section{Method}

Due to the exploratory nature of this study, an individual in-depth, semi-structured interview was chosen as the best means for obtaining data (see the Appendix for the preliminary interview guide). This was because individual in-depth interviews "allow the interviewer to delve deeply into social and personal matters" (DiCicco-Bloom \& Crabtree, 2006, p. 315). For semi-structured interviews, Rowley (2012) recommends creating "an interview schedule that centres on around six to 12 well chosen and wellphrased questions to be delivered mostly in a set order, but with some flexibility" ( $p$. 262). These questions should be open-ended in order to allow the participant to consider specific topics and respond in their own words, thereby "leading the interviewer towards areas of greatest import to the [participant]" (Dick, 2006 as cited by Warren \& Karner, 2010, p.157). For example, instead of asking a participant, "Do you use the public library to find information?" one could ask, "What sources do you find useful when seeking information?" In this way, the participant is invited to speak at length about all of the places they find information and not just whether or not they use the public library. This can in turn lead to the discovery of which sources the participant finds to be the most helpful.

The semi-structured nature of the interview also means other questions can emerge and be discussed throughout the course of the interview to provide added perspective with regards to the participant's experiences (DiCicco-Bloom \& Crabtree, 
2006, p. 315). For example, if the participant mentions their primary source of information is other crafters, the researcher can follow up with a question such as: 'You've mentioned other crafters a couple of times; can you tell me more about the specific types of information they provide?" By deviating from the interview schedule in this way, the researcher is able to gain a broader understanding of the participant's knowledge on a particular subject.

The participant chosen for this interview is a woman in her early thirties who has requested that she be identified as Rose. Rose has more than 15 years of experience crafting textiles, and despite working full-time as a massage therapist, she still spends between 10-20 hours a week crafting. While Rose primarily knits and embroiders, she also knows how to sew, spin, weave, crochet, and do bobbin lace. Rose actively participates in the Society for Creative Anachronism (SCA), Embroiderers Guild, and Lacemakers Guild and is an associate member of both the Rug Hookers and the Spinning and Weaving Guild. Rose also periodically teaches embroidery classes. Thus, given her expansive knowledge of the craft, Rose is an ideal candidate for exploring and understanding the information needs of textile artists.

The data gathered through Rose's interview was primarily coded using directed content analysis. "The goal of a directed approach to content analysis is to validate or extend conceptually a theoretical framework or theory" (Hsieh \& Shannon, 2005, p. 1281). During the initial phase the four broad categories outlined in Table 1 were employed to locate and code references related to information barriers and potential solutions to the barriers. References related to information resources were also noted during this phase, but these were not coded. This method helped the author become 
acquainted with the data set, organize the data set, and begin classifying, coding, and interpreting the data set (Rowley, 2012, p. 268). At this point a second phase of coding began using only the data related to the information resources. During this phase conventional content analysis was used to sort and classify the resources. This method allowed categories of sources for the resources to develop from the data rather than relying on preconceived notions (Hsieh \& Shannon, 2005, p. 1279).

\section{Findings}

\section{Sources and Resources}

The analysis of Rose's interview revealed five sources that textile artists utilize for locating resources to meet their information needs. These five sources and the various resources they contain are outlined in Table 2. In some cases multiple sources contained the same type of resource, such as texts, images, and patterns. These resources have been set in bold type, so the reader can distinguish which resources are unique to a particular source and which are not.

\begin{tabular}{|l|l|}
\hline \multicolumn{2}{|c|}{ TABLE 2: Information Sources and Resources } \\
\hline Sources & \multicolumn{1}{c|}{ Resources } \\
\hline Community & - email chains and mailing lists \\
- exemplars & - experts/community members \\
& - events (i.e. demonstrations, vendors, materials, equipment, etc.) \\
& - materials and equipment \\
& - material and technique classes, lessons, demonstrations \\
& - networks \\
& - patterns \\
& - texts (i.e., guild and member libraries) \\
\hline Experiential & - experimentation \\
& - practice \\
\hline
\end{tabular}




\begin{tabular}{|l|l|}
\hline Internet & $\begin{array}{l}\text { - Google searches (i.e., images, patterns, techniques, etc.) } \\
\text { - social media networks (i.e., Facebook, blogs, etc.) } \\
\text { - websites (e.g., Ravelry) }\end{array}$ \\
\hline Libraries & $\begin{array}{l}\text { - images } \\
\text { - librarian } \\
\text { - primary sources (i.e., movies, music, etc.) } \\
\text { - texts (i.e., books, periodicals, magazines, etc.) }\end{array}$ \\
\hline Museums & $\begin{array}{l}\text { - archivists } \\
\text { - images } \\
\text { - primary sources (i.e., original garments and paintings) } \\
\text { - texts }\end{array}$ \\
\hline Personal & $\begin{array}{l}\text { - class notes/handouts } \\
\text { - family and friends outside the community (e.g., opinions) } \\
\text { - texts (i.e., personal library) }\end{array}$ \\
\hline
\end{tabular}

The only instance in which multiples have not been set in bold type is "primary sources" in libraries and museums. This is because the resources that "primary sources" refer to in each category are fundamentally different. For instance, when Rose discussed her current knitting project - a reproduction of $17^{\text {th }}$ century knit garters - she noted that the only source for information was a preserved set housed in a museum. Meanwhile, a future project she hopes to undertake is a historically accurate dress for the unicorn in The Last Unicorn film, which will require her to examine the animated motion picture as a primary source:

Once I realized that it's a, I think, $13^{\text {th }}$ century French gown, just worn sort of wrong because it's not supposed to fit her right, and then I was looking for pictures from the animation of her, and mostly what I was getting were other people's costumes, which were not faithful reproductions, and so if I had gone 
from them it would have been inaccurate information. So I really had to make sure that I was getting primary sources as much as possible.

\section{Information Barriers}

Rose's interview also revealed eight information barriers, which are arranged in Table 3 under the four board categories.

\begin{tabular}{|c|c|c|c|}
\hline \multicolumn{4}{|c|}{ TABLE 3: Information Barriers } \\
\hline Individual & Social & $\begin{array}{c}\text { Information } \\
\text { Provider }\end{array}$ & Information Itself \\
\hline $\begin{array}{l}\text { - gender } \\
\text { stereotypes (i.e., } \\
\text { stigma) }\end{array}$ & $\begin{array}{l}\text { - financial } \\
\text { limitations (i.e., } \\
\text { expensive books, } \\
\text { materials, etc.) } \\
\text { - gendered group } \\
\text { dynamic (i.e., } \\
\text { insider/ outsider) }\end{array}$ & $\begin{array}{l}\text { - inaccurate } \\
\text { Google search } \\
\text { results } \\
\text { - limited access to } \\
\text { primary resources } \\
\text { - archivist not an } \\
\text { expert }\end{array}$ & $\begin{array}{l}\text { - poor quality } \\
\text { - unavailable (i.e., } \\
\text { pattern is out-of- } \\
\text { print or was not } \\
\text { posted) }\end{array}$ \\
\hline
\end{tabular}

It is worth noting that although financial limitations may seem like a barrier related to the individual, according to Savolainen (2016) economic capital is a type of privilege. "Since economic resources are not distributed equally across the population, disadvantaged people are more likely to face economic barriers to information seeking" (Savolainen, 2016, p. 56). Therefore, Rose's individual financial limitations fall under the social category rather than the individual category.

Gender appears in both the individual and social categories because it is a multifaceted issue. Individually, men may experience fear or embarrassment for wanting 
to learn about textile crafts because society has stereotypically labeled them as inherently feminine. Socially, women may consciously or unconsciously buy into this societal stereotype and create an exclusively female space. As Rose said when discussing one of the guilds, "In some of their language, the idea of men within their ranks is treated as a novelty, as opposed to, some men are humans who like doing art as well." This kind of structure and attitude can cause men to feel like unwelcome outsiders and further dissuade them from wanting to learn about textile crafts.

\section{Strategies for Circumnavigating Barriers}

Interestingly, the analysis of Rose's interview revealed not only common barriers textile artists face when seeking information, but also various ways in which they could circumnavigate and/or deal with those barriers. These potential solutions are outlined in Table 4.

\begin{tabular}{|l|l|}
\hline \multicolumn{2}{|c|}{ TABLE 4: Information Barrier Solutions } \\
\hline \multicolumn{1}{|c|}{ Bpecific } & \multicolumn{1}{c|}{ Potential Solutions } \\
\hline $\begin{array}{l}\text { Gender } \\
\text { stereotypes } \\
\text { (i.e., stigma) }\end{array}$ & $\begin{array}{l}\text { - Encouraging interest and the idea that "it's not un-manly to } \\
\text { gender has nothing to do with your interests } \\
\text { - Creating a gender neutral after-school program } \\
\text { - Promoting the value of knitting for developing hand-eye } \\
\text { coordination and helping kinesthetic learners focus in class }\end{array}$ \\
\hline $\begin{array}{l}\text { Financial } \\
\text { limitations } \\
\text { (i.e., expensive } \\
\text { books, }\end{array}$ & $\begin{array}{l}\text { - Borrow books from community members or the library } \\
\text { - Have a system for buying books (e.g., Rose only buys books } \\
\text { - Use mannmade fibers instead of natural fibers (e.g., Rose }\end{array}$ \\
\hline
\end{tabular}




\begin{tabular}{|c|c|}
\hline materials, etc.) & $\begin{array}{l}\text { used Tencel, an appropriate manmade simulacrum, instead of } \\
\text { silk for her } 17^{\text {th }} \text { century knit garters) } \\
\text { - Pass along unused resources, materials, and equipment to } \\
\text { community members }\end{array}$ \\
\hline $\begin{array}{l}\text { Gendered } \\
\text { group dynamic } \\
\text { (i.e., } \\
\text { insider/outsider) }\end{array}$ & $\begin{array}{l}\text { - Addressing the issue directly by finding out if there is a } \\
\text { reason why these women are potentially uncomfortable with } \\
\text { having men in this traditionally female space. And, if so, how } \\
\text { we can make women more comfortable with having men in the } \\
\text { group?² } \\
\text { - Encouraging male interest in the craft } \\
\text { - Creating a more inclusive and welcoming atmosphere }\end{array}$ \\
\hline $\begin{array}{l}\text { Inaccurate } \\
\text { Google search } \\
\text { results }\end{array}$ & $\begin{array}{l}\text { - Cross-reference (e.g., Rose wanted to make a rutabaga } \\
\text { crown, but Google kept giving her images of turnips, so she } \\
\text { went to her local grocery store's produce aisle and then to an } \\
\text { encyclopedia) }\end{array}$ \\
\hline $\begin{array}{l}\text { Limited access } \\
\text { to primary } \\
\text { resources }\end{array}$ & $\begin{array}{l}\text { - Request high-quality, close-up pictures, if some do not } \\
\text { already exist (e.g. Rose could not have accurately recreated } \\
\text { her } 17^{\text {th }} \text { century knit garters without the museum posting } \\
\text { pictures of the set they house) } \\
\text { - Contact the institution to request any additional information } \\
\text { required (e.g., if photos of the back of a garment do not exist, } \\
\text { email and ask if some could be taken and posted) }\end{array}$ \\
\hline $\begin{array}{l}\text { Archivist not an } \\
\text { expert }\end{array}$ & $\begin{array}{l}\text { - Bring in a textile expert to help appropriately catalogue items, } \\
\text { so accurate information can be conveyed (e.g., Rose once } \\
\text { saw a distaff labeled as a spindle) }\end{array}$ \\
\hline $\begin{array}{l}\text { Poor quality } \\
\text { information }\end{array}$ & $\begin{array}{l}\text { - Ask others' opinions } \\
\text { - Compare multiple texts and/or resources } \\
\text { - Use what you know from your own experience }\end{array}$ \\
\hline
\end{tabular}

\footnotetext{
2 Rose did state that "there are legitimate reasons why a woman might be uncomfortable with men in her traditionally female space," but she also did not think that should stop the group from trying to address the issue and finding a way to welcome men who are genuinely interested in textile artistry.
} 


\begin{tabular}{|c|c|}
\hline & $\begin{array}{l}\text { - Trial and error (i.e., try the gauge the resource recommends } \\
\text { and if the size is too big, then start again with a smaller gauge) }\end{array}$ \\
\hline $\begin{array}{l}\text { Unavailable } \\
\text { information (i.e., } \\
\text { pattern is out- } \\
\text { of-print or was } \\
\text { not posted) }\end{array}$ & $\begin{array}{l}\text { - If something is out-of-print, see about getting permission to } \\
\text { post it online } \\
\text { - Encourage more people to provide their patterns through } \\
\text { open source resources } \\
\text { - If a shawl was posted without an accompanying pattern and it } \\
\text { interests you, see if you can contact the poster for the pattern }\end{array}$ \\
\hline
\end{tabular}

Although many of these solutions require the textile artist to take the initiative, such as creating a system for buying books, cross-referencing resources, or using their own experience and trial-and-error, there are several solutions Rose mentioned that allow information professionals - both librarians and archivists - to take the initiative. For instance, when access to primary resources like garments is limited or the information required is incomplete, the best solution for a textile artist is to request additional information from the institution housing the garment. However, this can sometimes feel intimidating. As Rose said, "You sometimes have that worry of, I don't, I don't wanna, you know, interrupt their work, or get in the way, or anything, [by asking] annoying questions." A simple solution would be to clearly post signs - or messages on websites - stating (1) it is okay to ask questions and (2) where specifically individuals can direct those questions. Table 5 outlines both which potential solutions information professionals can take the initiative on and how they can implement those solutions.

\begin{tabular}{|l|l|l|}
\hline \multicolumn{3}{|c|}{ TABLE 5: Implementing Solutions } \\
\hline \multicolumn{1}{|c|}{ Barrier } & \multicolumn{1}{|c|}{ Potential Solution } & Potential Implementation \\
\hline Gender & Encouraging male interest in & Library or Museum: \\
\hline
\end{tabular}




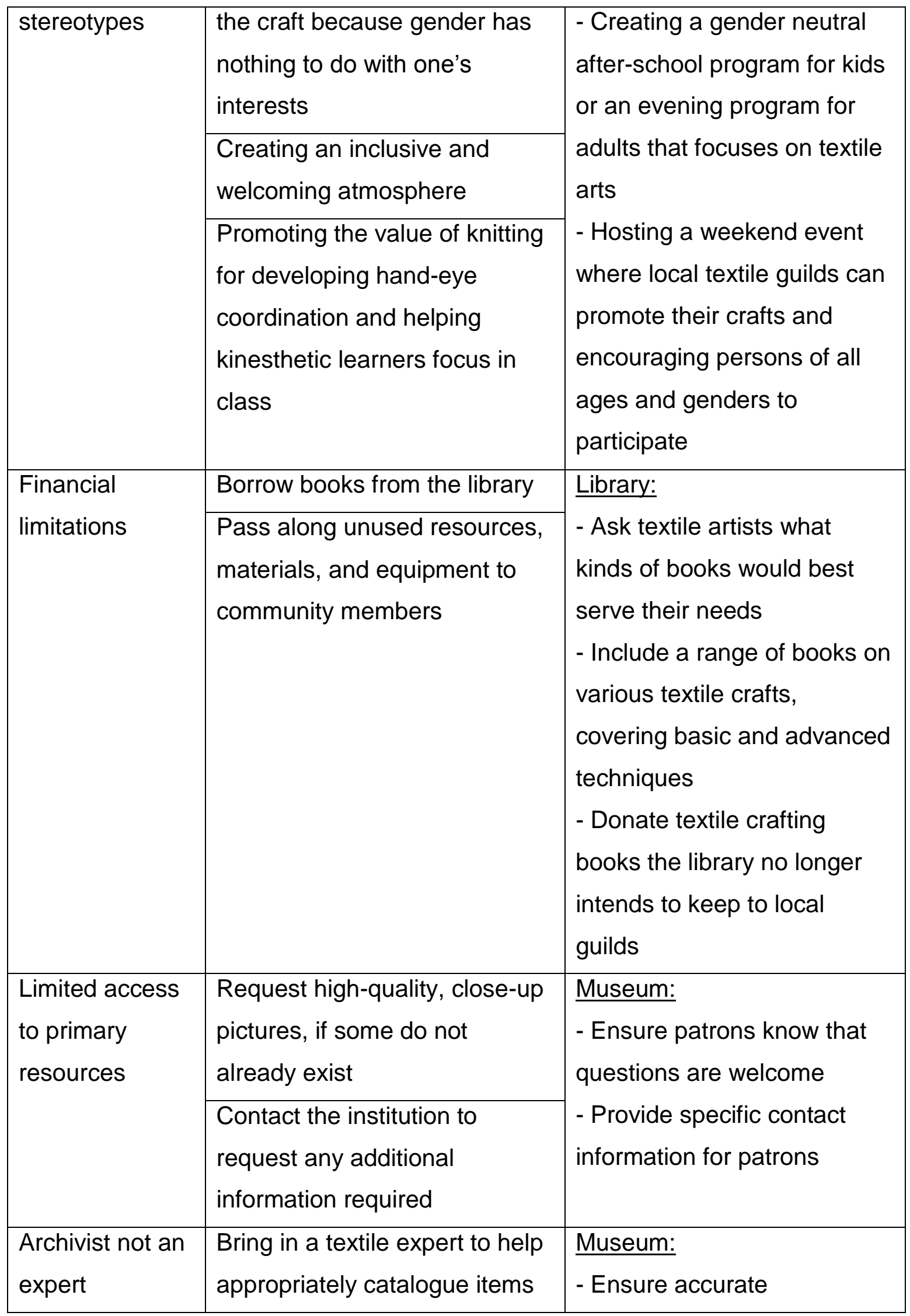




\begin{tabular}{|l|l|l|}
\hline & & $\begin{array}{l}\text { information is being } \\
\text { conveyed by inviting textile } \\
\text { art experts to help with the } \\
\text { cataloguing process }\end{array}$ \\
\hline $\begin{array}{l}\text { Unavailable } \\
\text { information }\end{array}$ & $\begin{array}{l}\text { Encourage more people to } \\
\text { provide their patterns through } \\
\text { open source resources }\end{array}$ & $\begin{array}{l}\text { Library: } \\
\text { - Provide information to } \\
\text { textile program and guild } \\
\text { participants about the } \\
\text { benefits of open source } \\
\text { resources as well as where } \\
\text { they can be found and how } \\
\text { to post on them }\end{array}$ \\
\hline
\end{tabular}

\section{Discussion}

\section{Sources}

For Rose, the largest source of resources by far was the textile artist community. Rose's participation in various guilds provides her with access to a breadth of resources and experiential knowledge that she could not have otherwise obtained. In fact, when asked directly what information sources she uses the most, Rose replied:

People. It depends a lot on what type of project l'm [doing], but I learn best from Socratic method and from lectures, so talking to people, asking questions, it both helps to help me find the answer that I need and also if it's a matter of opinion on something, then sometimes I find asking for someone else's opinion of something, even if mine actually differs from theirs, helps me to figure out what mine is. 
As noted in the literature review, this is not a unique phenomenon. Studies have consistently shown that artists of all types feel their communities provide a vital resource, particularly in terms of techniques, materials, and career guidance (Cobbledick, 1996; Prigoda \& McKenzie, 2007; Hemmig, 2008; Hemmig, 2009; Medaille, 2010; and Mason \& Robinson, 2011). When asked if she believed this was especially true of textile artists, since she so often sought information from her community, Rose responded:

I think crafting generally does, in that there are different groups of people, and you want to share the information, you want to share what you're doing. [...] So people are really keen to share their research, their resources, their talents, their information, because there is sometimes a bit of a lack. But generally speaking again, back to the idea of textiles especially as being more of a feminine craft there is a sense of camaraderie, of, you know, we're all in this together, we do have this thing in common... women sticking together and doing the thing that maybe has been derided as being feminine, and we're just saying, "No, we really like it."

In their observational study of a knitting circle, Prigoda and McKenzie (2007) confirmed that not only does the sharing of information about patterns and techniques serve to further social bonds, promoting both caring for the self and for others; it also promotes generational caring for the craft (pp. 105-106). "Through their craft production, the women assumed the role of caretaker to the craft, and a promoter of its continuation" (Schofield-Tomschin \& Littrell, 2001, p. 47). This social and traditional 
context perhaps speaks to the large role community plays in providing textile artists with information resources.

Another factor that might be at least partially responsible is the fact that artists prefer to learn by watching and doing over reading. "After simple experimentation, the artists' most preferred method of learning about materials and techniques is contact with their colleagues, followed by classes and demonstrations" (Hemmig, 2009, p. 691). This reliance on interpersonal resources, particularly for historical information in Rose's case, also seems to confirm the existence of invisible colleges among textiles artists. ${ }^{3}$ As Rose said, "I've been warned about certain sources as far as historical accuracy for medieval work, so in that case I'll ask someone I know to be fairly qualified or knowledgeable." In fact, the SCA's communication system, of which Rose facilitates a large part, appears to fit the very definition of an invisible college.

Rose: So I have become our local Arts \& Sciences Minister, which means that people tell me what kinds of things they're doing, I try to encourage people to do more things, I report on that because we are a non-profit so it's important to show that we are learning and teaching things, and also if people have questions about "hey, I want to learn this sort of thing" or "does anyone know about this sort of thing," I can be a resource, a touchpoint, on that to say, "oh, hey, I know someone is looking for information on this; here's a blacksmith, go talk to them; here's a weaver, go talk to them," right. So I can kind of collate who does what, especially

\footnotetext{
3 The concept of invisible colleges, which was first suggested to be applicable to artists by Cobbledick (1996), refers to an underlying structure of science that operates as a communications system with formal and informal functions (Wagner, 2010).
} 
in [the London] area, to give people more connections. Facebook: so helpful.

Author: Do you keep a specific list, or do you just keep it all in your head?

Rose: No, it's a specific list. And then within the Society there are different groups, there are different guilds, there's, you know, the unofficial guilds like the embroiderers, the lacemakers, the weavers; and those are just Facebook-based groups, but even someone who wasn't on Facebook but still did that thing in the Society would be counted in that group, where, you know, we share information, we ask questions, we just show what we're working on because we all love the pretty.

These networks of interpersonal resources within the textile artist community, which occur online through social media as well as offline ${ }^{4}$, are important to understand because they can guide information professionals in the types of information textile artists are likely to request. As Cobbledick (1996) recommended, "It is good to keep in mind not only what artists use the library for but also what they do not use it for" (p.364). For example, Rose will go to the library for inspiration, some primary sources, or even the aid of a librarian, but she will not go to the library for information on materials or equipment. This does not mean, however, that the library should cease carrying books about textile materials or equipment, but rather that they could save money and shelf space by asking an expert to recommend the best two or three books to have on the subject. This way the library has resources available should a program or someone

\footnotetext{
${ }^{4}$ In fact, except for specific websites and inspirational searches, all of the Internet resources can be directly traced back to the community as resources.
} 
lacking community connections need them without creating waste. It may also be advisable, given this deep need for community, that the library cultivate a contact list for anyone new to the area - or craft - looking to talk to an expert or join a guild.

\section{Resources}

The most common resource Rose sought from her sources was texts (i.e. books, periodicals, magazines, etc.), which is surprising given that previous research typically emphasizes images as artists' primary resource. For instance, Cobbledick (1996) listed specific visual elements as one of the five purposes for which artists seek information and other researchers have highlighted images as a primary source of inspiration. Even when texts are mentioned in the literature, they are often grouped together with images (Hemmig, 2009; Mason \& Robinson, 2011; Beaudoin, 2014; and Lo \& Chu, 2015). According to Cobbledick (1996), "Print materials constitute the single most important source of inspirational and/or visual information" (p. 361). Likewise, Hemmig (2009) classifies images and texts together when ranking sources of inspiration. ${ }^{5}$ And yet, books represent a wealth of information beyond the pictures located within their pages. In a breakdown from Mason and Robinson's (2011) research, emerging artists were found to use books for inspiration (96 percent), to find specific images or visual references (86 percent), to learn about the lives or works of other artists (77 percent), to investigate new techniques and materials (64 percent), and to locate information on funding and grants (32 percent) (p. 166). For Rose, texts fell almost exclusively into the fourth category:

\footnotetext{
${ }^{5}$ Admittedly, Hemmig (2009) does separate texts from images when ranking technical (i.e. materials and techniques) and business (i.e. shows, commissions, and sales) information, but, even so, texts do not rank first in either category.
} 
I do find books are helpful, especially for more traditional techniques, or simply finding knitting patterns, especially sometimes sewing or embroidery, something that I like, and I may or may not recreate it fully; I might say, I really like that idea, I'm going to do something really similar. But l'll go to books either for techniques or for specific patterns.

This deviation from the norm may be specific to textile artists. In her study of theatre artists, Medaille (2010) found that texts were theatre artists' primary source for inspiration. Unlike with other types of artists, images were neither on the list for sources of inspiration nor on the list of purposes for information seeking (Medaille, 2010, p 334, 336). This is likely due to the fact that a theatre artist's world revolves around the playscript, a text which "they spend much of their time studying and responding to" as well as the fact that in preparation for a production, theatre artists often conduct extensive research (Medaille, 2010, p. 334). For example, the "costume designer called her research the 'building block... what you build everything else on'” (Medaille, 2010, p. 334). Thus, it is possible that textile artists, with their heavy reliance on patterns, materials, and techniques, may gravitate more towards texts rather than images as primary resources. Yet, it is worth noting that Rose's second most commonly soughtafter resource was images, so it is possible that further study would reveal that Rose is the exception rather than a representative example.

Regardless, "in the context of a public library, informing is most likely to happen through users' interactions with texts" (Leckie \& Given, 2005, p. 3). Thus, it is strongly recommended that librarians consider consulting textile artists on the types of texts they need and/or would like to see in the library. Additionally, Prigoda and McKenzie (2007) 
found that knitters often "supplemented the library's collection with their own materials" (p. 102). Consequently, it may also be beneficial for librarians to consider coordinating with local textile guilds, as they often have their own libraries that could be used to complement, or even potentially supplement, the library's collection.

\section{Barriers \& Strategies for Circumnavigating Them}

At the heart of the barriers facing textile artists are two principle concerns: the inaccessibility of information and the unsatisfactory quality of information. These are both concerns that information professionals are capable of successfully managing. In fact, in the case of the first concern, the Library Bill of Rights specifically mandates that "books and other library resources should be provided for the interest, information, and enlightenment of all people of the community the library serves" (American Library Association [ALA], 2019c). Therefore, it is part of a librarian's duty to ensure that they are doing everything within their power to improve individuals' access to information. For example, as noted above, financial limitations can be a barrier to accessing information, which is why the American Library Association, in accordance with the Library Bill of Rights, opposes user fees:

Charging fees for the use of library collections, services, programs, or facilities that were purchased with public funds raises barriers to access. Such fees effectively abridge or deny access for some members of the community because they reinforce distinctions among users based on their ability and willingness to pay. (ALA, 2019a)

The Library Bill of Rights also offers some guidance for librarians in the case of the second concern: poor quality information. First, continuous review and evaluation of 
the library's collection ensures that physically deteriorating or obsolete materials are replaced or removed "as a means of maintaining an active library collection of current interest to users" (ALA, 2019b). This will help to ensure that textile artists have access to suitable and current resources. Second, as demonstrated in both Rose's resource list (Table 2) and the proposed solutions to the barriers she has encountered (Table 4), online information and networks play a considerable role in satisfying her information needs. This is why it is vital that individuals lacking in digital literacy skills be offered opportunities to learn and/or improve those skills. According to the Library Bill of Rights, "Libraries and librarians protect and promote [freedom of speech and the right to receive information] by selecting, producing, providing access to, identifying, retrieving, organizing, providing instruction in the use of, and preserving recorded expression regardless of the format or technology" (ALA, 2019b). Thus, providing programs that teach textile artists how to perform effective Internet searches or efficiently and successfully cross-reference information, as well as providing digital resources on the topic such as a LibGuide or a compilation of recommended websites, will not only benefit textile artists; such efforts will also be in keeping with the Library Bill of Rights.

Despite the many and varied things information professionals - particularly librarians - can do to mitigate the information barriers textile artists face, there are some barriers that they cannot solve. For example, in the case of gendered group dynamics, the best option is for textile artists participating in the group to address the issue amongst themselves. In this way, they will be able to determine the cause of the issue as well as the most appropriate method for overcoming it. Likewise, some of the solutions proposed by Rose cannot be implemented by information professionals, as 
they must instead be implemented by textile artists themselves. For example, if a pattern's information is unavailable and the creator cannot be reached, a textile artist's best option might be to use his or her own experience in addition to the trial-and-error method to figure out the pattern. Thus, it is important for information professionals to recognize the limits in their abilities to assist textile artists. That way, information professionals can concentrate their efforts on the things they can solve, such as offering free resources and programs, encouraging male interest, posting open source resources, and inviting experts to aid in cataloguing and collection efforts.

\section{Conclusion}

It is important to note that this study is based solely on the interview of one textile artist and is therefore limited in scope. Although several barriers were identified, it is possible that more remain. It is also possible that additional solutions to the identified barriers exist. Future studies should include a larger sampling of textile artists ranging both in skill level (i.e., beginners, hobbyists, and experts) and primary textile craft (i.e., knitting, embroidery, crochet, etc.), since, as Mason and Robinson (2011) demonstrated, different artists may face different information barriers. Moreover, future studies should also examine the barriers that other types of artists, such as painters, sculptors, and actors, face when seeking information. Nevertheless, this paper provides a sound starting point for researchers interested in investigating the barriers that artists, particularly textile artists, face when seeking information. Moreover, it also provides some practical solutions for information professionals to implement in order to mitigate the negative impact of these barriers. In this way, it is the author's hope that 
researchers and practitioners can together begin working with artists to mend the torn seams in the complex tapestry of their information needs. 


\section{References}

American Library Association. (2019a). Economic barriers to information access.

Retrieved from

http://www.ala.org/advocacy/intfreedom/librarybill/interpretations/economicbarrier

$S$

American Library Association. (2019b). Interpretations of the Library Bill of Rights.

Retrieved from http://www.ala.org/advocacy/intfreedom/librarybill/interpretations

American Library Association. (2019c). Library Bill of Rights. Retrieved from

http://www.ala.org/advocacy/intfreedom/librarybill

Beaudoin, J. E. (2014). A framework of image use among archaeologists, architects, art historians and artists. Journal of Documentation, 70(1), 119-147. doi:10.1108/JD$12-2012-0157$

Chatman, E. A. (1996). The impoverished life-world of outsiders. Journal of the American Society for Information Science (1986-1998), 47(3), 193.

Chatman, E. A. (1999). A theory of life in the round. Journal of the American Society for Information Science, 50(3), 207.

Cobbledick, S. (1996). The information-seeking behavior of artists: Exploratory interviews. The Library Quarterly: Information, Community, Policy, 66(4), 343372. doi:10.1086/602909 
Craft. [Origin]. (n.d.). In English Oxford Living Dictionaries. Retrieved July 24, 2018, from https://en.oxforddictionaries.com/definition/craft

DiCicco-Bloom, B., \& Crabtree, B. F. (2006). The qualitative research interview. Medical Education, 40(4), 314-321. doi:10.1111/j.1365-2929.2006.02418.x

Harris, R. M., \& Dewdney, P. (1994). Barriers to information: How formal help systems fail battered women. Westport, Conn: Greenwood Press.

Hayter, S. (2006). Exploring information worlds in a disadvantaged community: A UK perspective. Canadian Journal of Information and Library Science, 30(1-2), 21.

Hemmig, W.S. (2008), The information-seeking behavior of visual artists: A literature review. Journal of Documentation, 64(3), 343-62.

doi:10.1108/00220410810867579

Hemmig, W. (2009). An empirical study of the information-seeking behavior of practicing visual artists. Journal of Documentation, 65(4), 682-703.

doi:10.1108/00220410910970302

Hsieh, H-F., \& Shannon S. E. (2005). Three approaches to qualitative content analysis. Qualitative Health Research, 15(9), 1277-1288. doi:10.1177/1049732305276687

Lave, J., \& Wenger, E. (1991). Situated learning: Legitimate peripheral participation. Cambridge: Cambridge University Press.

Leckie, G. J., \& Given, L. M. (2005). Understanding information-seeking: The public library context (pp. 1-72). Emerald Group Publishing Limited. doi:10.1016/S00652830(05)29001-3 
Lo, P., \& Chu, W. (2015). Information for inspiration: Understanding information-seeking behaviour and library usage of students at the Hong Kong Design Institute. Australian Academic \& Research Libraries, 46(2), 101-120. doi:10.1080/00048623.2015.1019604

Mason, H., \& Robinson, L. (2011). The information-related behaviour of emerging artists and designers: Inspiration and guidance for new practitioners. Journal of Documentation, 67(1), 159-180. doi:10.1108/00220411111105498

Medaille, A. (2010). Creativity and craft: The information-seeking behavior of theatre artists. Journal of Documentation, 66(3), 327-347. doi:10.1108/00220411011038430

Poser, J. (2008). Contemporary craft: The look of labor. Art Education, 61(2), 80-86. doi:10.1080/00043125.2008.11651147

Prigoda, E., \& McKenzie, P. J. (2007). Purls of wisdom: A collectivist study of human information behaviour in a public library knitting group. Journal of Documentation, 63(1), 90-114. doi:10.1108/00220410710723902

Rowley, J. (2012). Conducting research interviews. Management Research Review, 35(3/4), 260-271. doi:10.1108/01409171211210154

Savolainen, R. (2009). Small world and information grounds as contexts of information seeking and sharing. Library and Information Science Research, 31(1), 38-45. doi:10.1016/j.lisr.2008.10.007 
Savolainen, R. (2014). Emotions as motivators for information seeking: A conceptual analysis. Library and Information Science Research, 36(1), 59-65. doi:10.1016/j.lisr.2013.10.004

Savolainen, R. (2015a). Cognitive barriers to information seeking: A conceptual analysis. Journal of Information Science, 41(5), 613-623. doi:10.1177/0165551515587850

Savolainen, R. (2015b). The interplay of affective and cognitive factors in information seeking and use: Comparing Kuhlthau's and Nahl's models. Journal of Documentation, 71(1), 175-197. doi:10.1108/JD-10-2013-0134

Savolainen, R. (2016). Approaches to socio-cultural barriers in information seeking. Library \& Information Research, 38, 52-59. doi:10.1016/j.lisr.2016.01.007

Schofield-Tomschin, S., \& Littrell, M. A. (2001). Textile handcraft guild participation: A conduit to successful aging. Clothing and Textiles Research Journal, 19(2), 4151. doi:10.1177/0887302X0101900201

Visser, M. (1994). The language of things. In G. Hickey (Ed.), Making and metaphor: A discussion of meaning in contemporary craft, (pp. 12-19). Ottawa, ON: Canadian Museum of Civilization and Institute for Contemporary Canadian Craft.

Wagner, C. S. (2010). Invisible college. In S. H. Priest (Ed.), Encyclopedia of science and technology communication (pp. 427-430). Thousand Oaks, CA: SAGE Publications, Inc. doi:10.4135/9781412959216.n145 
Warren, C. A. B., \& Karner, T. X. (2010). Discovering qualitative methods: Field research, interviews, and analysis ( $2^{\text {nd }}$ ed.). New York, NY: Oxford University Press.

\section{Appendix: Preliminary Interview Guide}

\section{Context}

- What first sparked your interest in textile art? (When?)

- What types of textile crafting or art do you do? (specific examples)

- Do you have a favourite or primary one?

- I know you participate in textile crafting groups; can you tell me a bit about these groups and why you joined them?

- I know you teach some types of textile art; what do you teach?

- How many hours on average do you think you spend on your textile art per week?

\section{Information Seeking}

- What kind of information do you need for you textile art? (specific examples)

- Do you have different needs for different types of textile art? (specific examples)

- What sources of information do you use most?

- How do you know if the information/source is good?

- Has the way you find information or the sources you use changed over time?

- Do the groups you participate in provide sources of information?

- What kinds of information do you provide to your students and why? 


\section{Information Barriers}

- What barriers have you encountered when attempting to locate information? (specific examples)

- How do you deal with those barriers?

- If you could change something about the barriers you face what would it be?

- What information would you say you need the most? 